\title{
Potential use of custirsen to treat prostate cancer
}

This article was published in the following Dove Press journal:

OncoTargets and Therapy

24 June 2013

Number of times this article has been viewed

\section{Celestia S Higano \\ Department of Medicine, University of Washington, and Fred Hutchinson Cancer Research Center, Seattle,WA, USA}

Correspondence: Celestia S Higano Seattle Cancer Care Alliance, 825 Eastlake Ave E, MS G4-830, Seattle, WA 98109-1023, USA

Tel + I 206288 II 52

Fax + I 2062882042

Email thigano@u.washington.edu
Abstract: Over the last few years, five agents have demonstrated a survival benefit over a comparator treatment or placebo in the treatment of metastatic castration-resistant prostate cancer and have been approved by the US Food and Drug Administration: sipuleucel-T (a dendritic cell immunotherapy); cabazitaxel; abiraterone acetate and enzalutamide (both hormonal agents); and radium 223 (an alpha emitter). The development of these agents pivoted on whether patients had been treated with docetaxel, which remains the first-line chemotherapy of choice. To date, no combination of docetaxel and another active agent has demonstrated superiority to docetaxel alone despite numerous Phase III trials. Clusterin is a cytoprotective chaperone protein that is upregulated in response to various anticancer therapies. When overexpressed, clusterin interferes with apoptotic signaling, thereby promoting cell survival and conferring broad-spectrum resistance in cancer cell lines. Custirsen (OGX-011) is a second-generation 2'-methoxyethyl modified phosphorothioate antisense oligonucleotide that inhibits expression of clusterin. This review presents the preclinical and clinical data that provided the rationale for the combination of custirsen with chemotherapy in ongoing Phase III trials.

Keywords: castration-resistant prostate cancer, clusterin, custirsen, OGX-011, antisense, OGX-427, apoptosis

\section{Introduction}

Prostate cancer is the most common cancer affecting men in the US (excluding nonmelanoma skin cancers), and is the second leading cause of cancer death among men. ${ }^{1,2}$ It was estimated that in 2012 there were more than 240,000 new cases in the US. ${ }^{2}$

Most patients with hormone-sensitive recurrent or metastatic prostate cancer will develop castration-resistant disease over time. Prior to 2004, when the US Food and Drug Administration approved docetaxel, chemotherapy had a limited role in the routine treatment of metastatic castration-resistant prostate cancer (mCRPC). However, based on two Phase III trials in mCRPC, in which docetaxel conferred a modest survival improvement of 2-2.5 months compared with mitoxantrone and prednisone, ${ }^{3,4}$ docetaxel became and has remained the preferred first-line chemotherapeutic agent for mCRPC. ${ }^{5}$

A substantial proportion of patients in the Phase III registration studies for docetaxel did not respond to docetaxel, ${ }^{3,4}$ and many responses were of less than six months' duration. ${ }^{4,6}$ This has prompted numerous attempts to improve on the outcomes of treatment with docetaxel. Docetaxel has been studied in combination with agents having 
numerous mechanisms of action, including immunotherapy (granulocyte-macrophage colony-stimulating factor gene-transfected tumor cell vaccine), antiangiogenesis (bevacizumab, aflibercept and lenalidomide), endothelin receptor inhibition (atrasentan and zibotentan), vitamin D ligand-mediated potentiation (calcitriol), and tyrosine kinase (src) inhibition (dasatinib). None of these combinations has proven to be superior to standard docetaxel and prednisone alone. $^{7-14}$

Since 2010, five additional agents, ie, sipuleucel-T, cabazitaxel, abiraterone acetate, radium 223, and enzalutamide, have shown a survival advantage in Phase III prostate cancer trials. ${ }^{15-19}$ Sipuleucel-T, a dendritic cell immunotherapy, was compared with placebo either before or after docetaxel therapy in men who had no or minimal symptoms. ${ }^{15}$ Cabazitaxel, a taxane, was compared with mitoxantrone ${ }^{16}$ and was approved as second-line chemotherapy after docetaxel. Abiraterone acetate and enzalutamide, both hormonal agents, were compared with prednisone or placebo, respectively. ${ }^{17,19}$ Radium 223, an alpha emitter, was compared with best supportive care. ${ }^{18}$

However, studies of the approved agents were conducted in either the pre-docetaxel or post-docetaxel setting, and none of these agents has been compared with docetaxel. Given the rapid entry of these new agents into the mCRPC treatment landscape, there is currently significant uncertainty about how to sequence therapy, and whether combinations of these agents confer additional benefits. Nonetheless, it is likely that chemotherapy will still play a significant role in the treatment of mCRPC, and hence strategies to augment the modest improvements in outcome are still needed. This article focuses on examining why clusterin is a rational target in mCRPC and why the antisense molecule to clusterin, custirsen, is currently being studied in combination with chemotherapy (docetaxel or cabazitaxel) in Phase III trials in men with mCRPC.

\section{Role of clusterin in prostate cancer}

Molecular chaperones, eg, heat-shock proteins, are thought to interact with unfolded or partially folded cellular proteins to prevent inappropriate aggregation, aberrant folding, or denaturation. They play a key role in the cell's response to stress and are also involved in regulating cell signaling and gene expression through their interactions with components of signal transduction pathways (reviewed by Gaeste ${ }^{20}$ and Vabulas et $\mathrm{al}^{21}$ ). Upregulation of molecular chaperones in tumor cells has been implicated in the survival mechanisms used by tumor cells to evade apoptosis induced by cancer therapies. $^{22}$

Clusterin is an ATP-independent chaperone protein with structural similarity to the heat-shock proteins, and is known to be overexpressed in many solid tumors (reviewed by Zoubeidi et $\mathrm{al}^{23}$ ). The clusterin gene is located on chromosome $8 \mathrm{p} 21-\mathrm{p} 12,{ }^{24}$ and is regulated by heat-shock factor-1. It encodes both cytoplasmic/secretory and nuclear forms of the protein (reviewed by Zoubeidi et $\mathrm{al}^{23}$ ). The roles and function of the nuclear form have not been extensively studied, but the cytoplasmic/secretory forms of clusterin are known to be expressed in most tissues and contribute to many normal physiological processes as well as several diseases, including Alzheimer's disease and cancer. ${ }^{25-28}$ There is evidence that stressful stimuli can result in retention of clusterin in the cytosol. ${ }^{29}$

Clusterin is thought to have multiple functions in the stress response and in cell survival pathways, ${ }^{23}$ but its mechanism of action is not yet fully understood. The cytoplasmic/ secretory forms of clusterin include protein-folding and oligomerization motifs, such as coiled-coil domains. ${ }^{23}$ These are thought to mediate its interaction with other proteins and macromolecular complexes. Biochemical studies have confirmed that clusterin can prevent protein precipitation in vitro to protect cells from stress-induced changes, ${ }^{30}$ and also indicate a role for both secreted and cytosolic clusterin in the clearance of misfolded proteins. ${ }^{29,31,32}$ Clusterin demonstrates antiapoptotic activity in prostate cancer cells, ${ }^{33}$ and has been shown to interact with several key protein complexes known to be involved in apoptosis and cell survival pathways associated with tumor progression. These include the proapoptotic Bcl-2-associated protein Bax, which is inhibited by binding of clusterin to conformationally altered Bax in the Ku70-Bax complex, ${ }^{34}$ the COMMD1/I- $\mathrm{BB}$ complex, through which clusterin indirectly regulates nuclear factor $(\mathrm{NF})-\kappa \mathrm{B}$ activity and signaling ${ }^{35}$ the extracellular signalregulated kinase ERK, and AKT kinase, which also acts upstream of NF- $\kappa \mathrm{B}$ (Figure 1). ${ }^{23}$ A role for clusterin in tumor invasiveness and metastasis has also been proposed because of its interaction with the ERK/slug pathway (Figure 1) and its role in transforming growth factor- $\beta$-promoted epithelialmesenchymal transition. ${ }^{36}$

Overexpression of clusterin has been detected in many tumor types, including prostate, breast, non-small cell lung, colorectal, ovary, bladder, and renal cancers, ${ }^{25,26,37-41}$ and it has been linked with more aggressive tumors and poorer outcomes. ${ }^{26,37,40}$ In prostate cancer, clusterin overexpression is associated with poor prognostic factors, such as high Gleason 


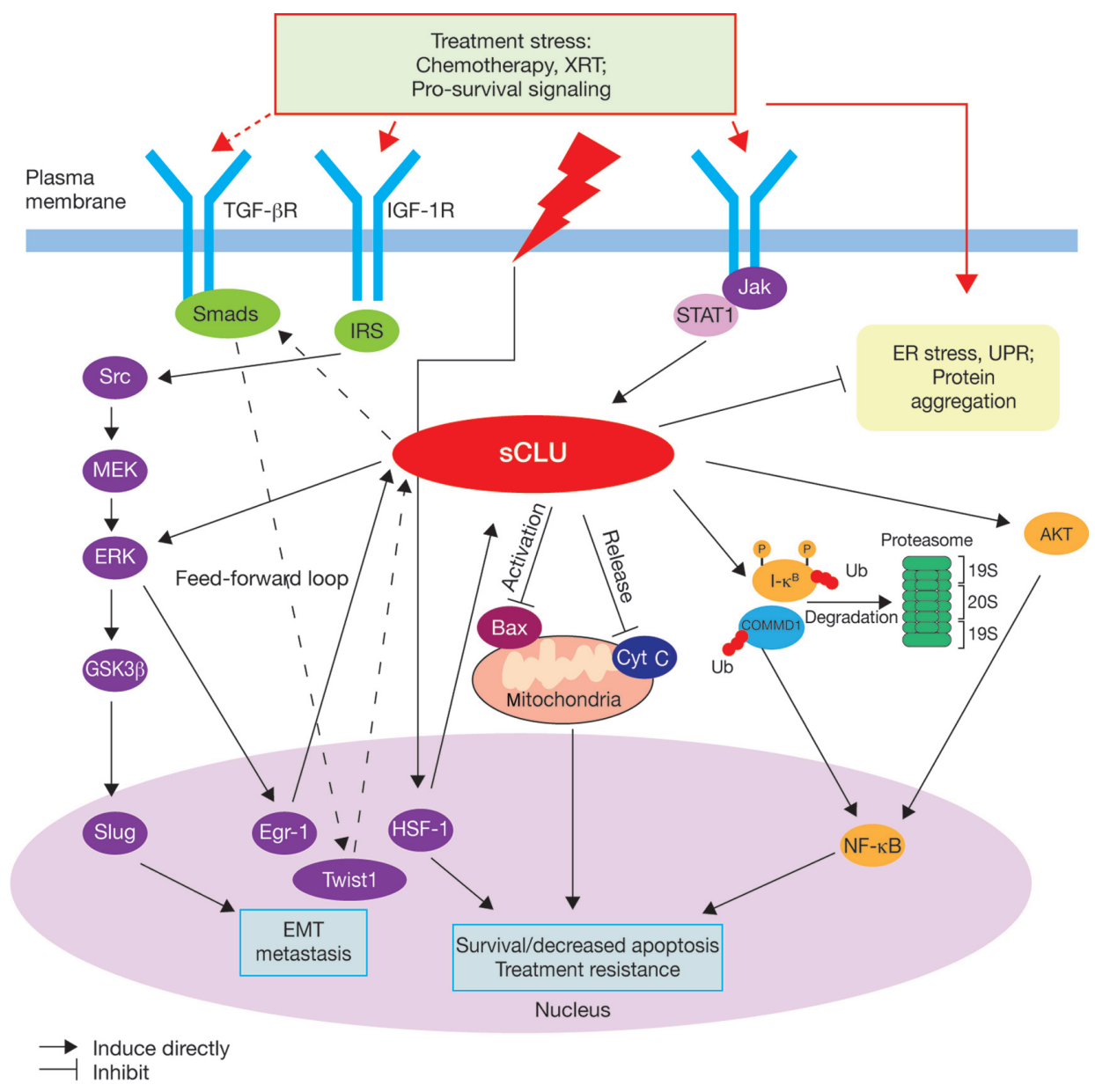

Figure I Proposed roles of cytoplasmic/secretory clusterin in tumor progression. ${ }^{23}$

Notes: Reprinted from Clinical Cancer Research 2010, volume 16, pages 1088-1093. Zoubeidi A, Chi K, Gleave M, Targeting the cytoprotective chaperone, clusterin, for treatment of advanced cancer, with permission from AACR. ${ }^{23}$ Adapted to show potential interaction between TGF- $\beta$, Twist I, and clusterin (dashed lines) based on Shiota et al. ${ }^{36}$ Abbreviations: Cyt C, cytochrome C; EMT, epithelial-mesenchymal transition; ER, endoplasmic reticulum; HSF, heat-shock factor; IGF-IR, insulin-like growth factor I receptor; IRS, insulin receptor substrate; Jak, janus kinase; sCLU, secretory clusterin; TGF- $\beta$, transforming growth factor-beta; Ub, ubiquitin; UPR, unfolded protein response; XRT, radiation.

score. ${ }^{40}$ Clusterin expression is known to be upregulated in patients with mCRPC after neoadjuvant hormone therapy, ${ }^{42,43}$ and in docetaxel-resistant prostate cancer cell lines. ${ }^{44,45}$ In experimental models, overexpression of clusterin in prostate cancer cell lines confers resistance to both antiandrogen therapy and chemotherapy with taxanes, ${ }^{46,47}$ and decreases radiosensitivity, with a concomitant decrease in radiationinduced apoptosis and arrest of growth. ${ }^{48}$ This evidence supports the hypothesis that clusterin plays a key role in the development of resistance to treatment by blocking therapy-induced apoptosis, and provides a strong rationale for targeting clusterin in prostate cancer.

\section{Targeting clusterin with antisense technology}

Antisense oligonucleotide (ASO) therapy targets specific functional genes. ASOs consist of single-strand DNA that is complementary to messenger (m)RNA expressed by the target gene. Binding of the ASO to mRNA creates a complex that inhibits translation of the mRNA and thus reduces levels of the protein encoded by the target gene. ASOs can also have "off-target" immunostimulatory effects related to certain sequences in the ASO. The phosphorothioate ASOs are water soluble and modified to resist nuclease digestion.

The use of ASOs to target synthesis of proteins involved in key steps of disease processes has been investigated in the clinic over the last few decades. The first-generation ASOs typically have short serum and tissue half-lives, and require continuous intravenous infusion. ${ }^{49}$ These pharmacologic properties led to limited success in the clinic, and a number of first-generation antisense approaches have failed to achieve regulatory approval to treat cancer. For example, oblimersen sodium, which inhibits bcl-2 expression, did not demonstrate a survival benefit in Phase III trials of melanoma or myeloma. ${ }^{50,51}$ 
Another first-generation antisense agent, ISIS 3521 (an inhibitor of protein kinase $c-\alpha$ ), did not meet its primary endpoint in a Phase III study in non-small cell lung cancer. ${ }^{52}$

Custirsen is a second-generation phosphorothioate ASO that binds to the translation initiation site of mRNA for human secretory clusterin. It differs from previous antisense approaches through the addition of 2 -methoxyethyl on the ribose groups of nucleotides at the ends of the phosphorothioate backbone (Figure 2). ${ }^{53}$ This modification is thought to confer higher affinity for the target $\mathrm{RNA}^{54}$ and improved resistance to nucleases, with a correspondingly prolonged tissue half-life of approximately seven days and hence a more convenient dosing schedule than first-generation ASOs. ${ }^{53}$ There is also some evidence suggesting that second-generation ASOs with 2 '-methoxyethyl modifications are less toxic and cause less nonspecific immune stimulation than unmodified ASOs. ${ }^{55}$ This may enable the use of higher doses.

OGX-427, which targets heat-shock protein 27 , is another second-generation antisense agent with the 2 -methoxyethyl modification. OGX-427 has shown promising antitumor effects in early clinical studies in both prostate and bladder cancers. ${ }^{56-58}$ LY2181308, a second-generation antisense agent that targets the cell survival protein survivin, has demonstrated activity in a Phase I study of patients with solid tumors. ${ }^{59}$

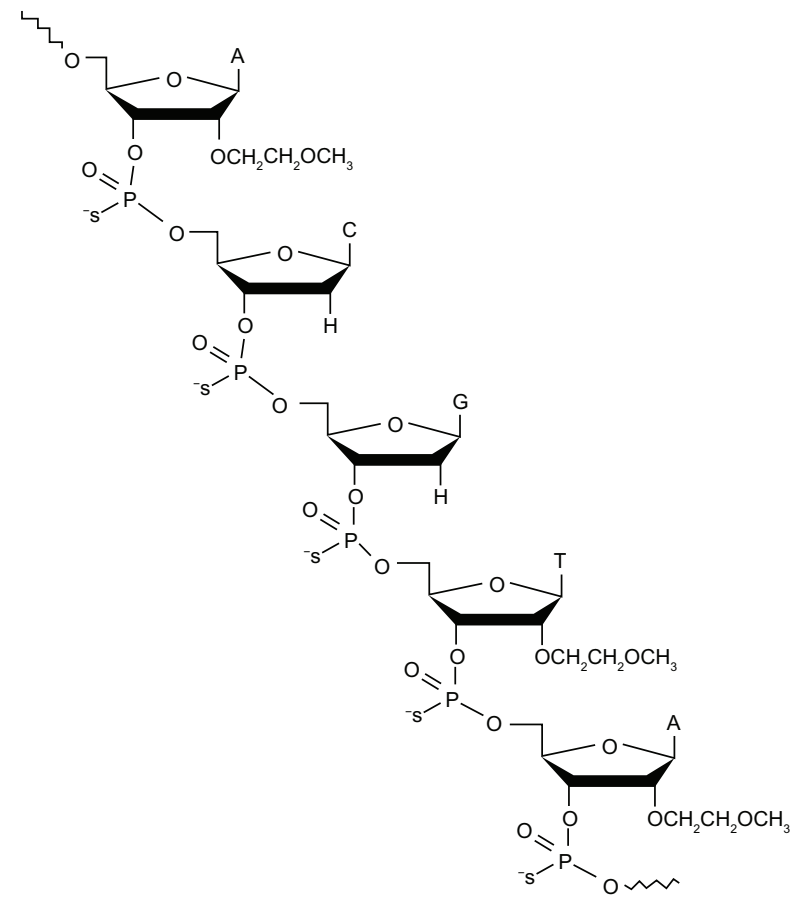

Figure 2 Structure of the 21 -mer custirsen antisense oligonucleotide to clusterin mRNA.

Notes: Republished with permission of Bentham Science Publishers, from Current Genomics, So A, Hadaschik B, Sowery R, and Gleave M, volume 8(4), pages 25I-26I, 2007. Permission conveyed through Copyright Clearance Center Inc.
Preliminary results in early phase studies suggest that, despite discouraging results with the first-generation antisense agents in cancer therapy, the improved pharmacokinetics of the second-generation antisense agents might result in improved outcomes using this approach.

\section{Preclinical studies of custirsen}

In vitro and in vivo experiments in various cancer cell lines confirm potent suppression of clusterin mRNA and protein levels by custirsen. ${ }^{45,53,60,61}$ In a docetaxel-resistant prostate cancer cell line and xenograft model (PC-3), addition of custirsen increased the rate of apoptosis and resensitized cells to docetaxel and paclitaxel (Figure 3). ${ }^{45,53}$ In animal models of prostate cancer, custirsen has been shown to increase apoptosis and resensitize treatment-resistant tumors to radiation, chemotherapy, and hormone therapy. ${ }^{45,62}$ Similar effects have been observed in other tumor types, including breast, lung, and bladder. ${ }^{61,63,64}$

\section{Efficacy of custirsen in clinical trials in prostate cancer}

To date, over 500 patients have been treated with custirsen in a comprehensive clinical development program encompassing multiple tumor types (prostate, breast, and non-small cell lung) and clinical settings (neoadjuvant, first-line, and second-line treatment in different combination regimens). A summary of published clinical trials of custirsen in prostate cancer is presented in Table 1 .

\section{Phase I studies of custirsen}

The first-in-human Phase I study established that custirsen was well tolerated with a predictable pharmacokinetic profile, and that there was a dose-dependent inhibition of clusterin expression with an associated increase in apoptotic index in primary prostate cancer tissue. ${ }^{65}$ Twenty-five patients with previously untreated localized disease and high-risk features (prostate-specific antigen [PSA] $>10 \mathrm{ng} / \mathrm{mL}$, stage T3 disease, Gleason score 7-10) who were candidates for radical prostatectomy were treated with androgen deprivation and custirsen by two-hour intravenous infusion on days 1, 3, and 5 , followed by weekly dosing, starting on day 8 , for four doses. Custirsen was administered in six dose cohorts of 40 , $80,160,320,480$, and $640 \mathrm{mg}$. Prostatectomy was performed within seven days of the final dose of custirsen. No doselimiting toxicity was observed at the maximum dose level of $640 \mathrm{mg}$. Both the area under the plasma concentration-time curve and the maximum plasma concentration of custirsen increased proportionally with dose. Custirsen concentrations 


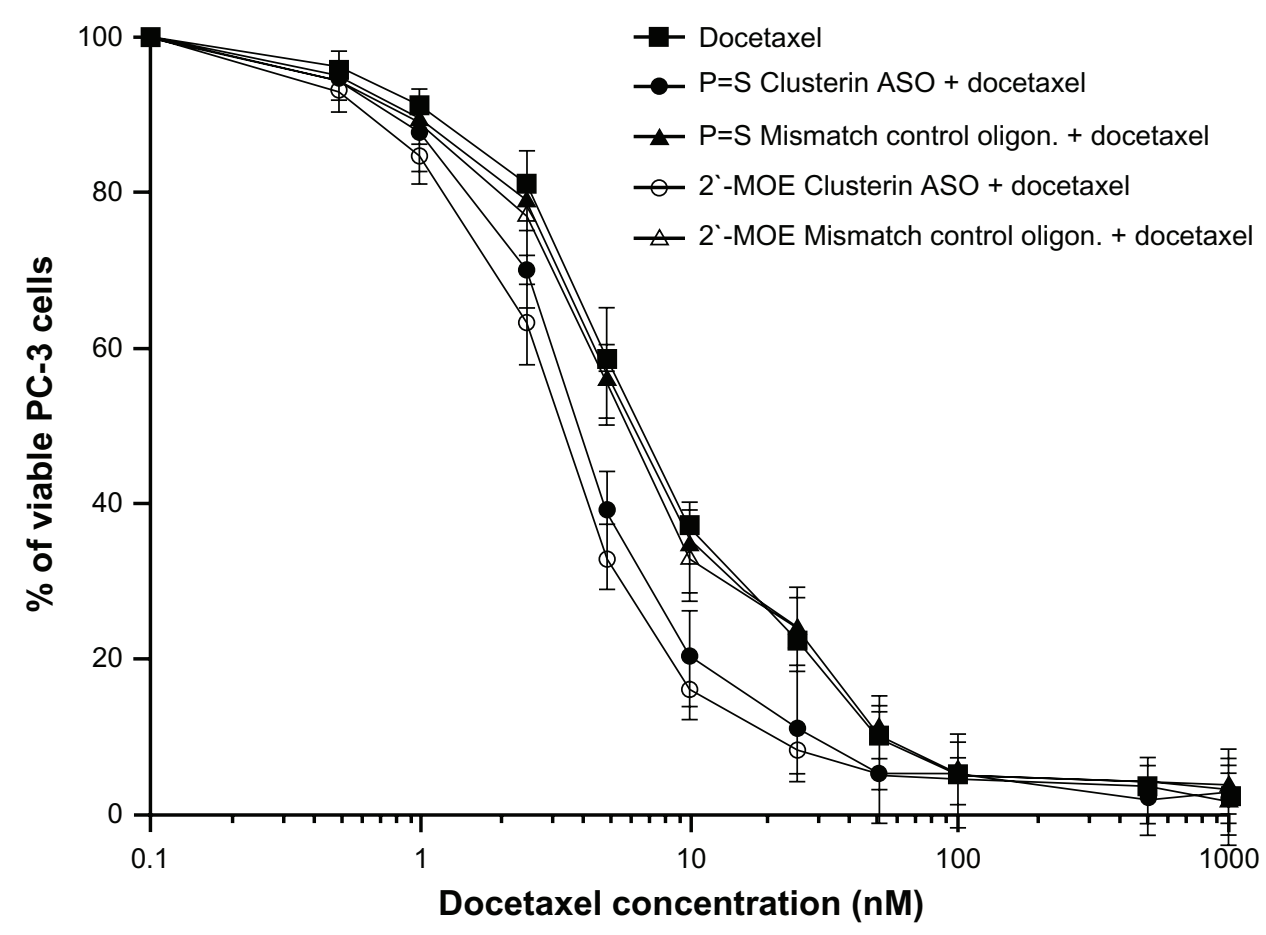

Figure 3 In vitro effect of 2'-methoxyethyl-modified custirsen and conventional custirsen ASOs on sensitivity of PC-3 cells to docetaxel. ${ }^{53}$

Note: Reproduced with permission from: Tobias Zellweger, Hideaki Miyake, Scott Cooper, Kim Chi, Boyd S. Conklin, Brett P. Monia, and Martin E. Gleave, Antitumor activity of antisense clusterin oligonucleotides is improved in vitro and in vivo by incorporation of 2'-O-(2-methoxy) ethyl chemistry, J Pharmacol Exp Ther. September I, 200I;298:934-940.53

Abbreviations: ASO, antisense oligonucleotide; MOE, methoxyethyl; oligon., oligonucleotide.

in prostate tissue also increased with dose. This study provided the first clinical evidence for the biological effect of custirsen, with dose-dependent decreases in clusterin expression of $>90 \%$ demonstrated in both prostate tissue and lymph nodes, and an associated significant increase in the apoptotic index in prostatectomy specimens (Figure 4). Based on the results of this study, the dose of $640 \mathrm{mg}$ was selected as a well tolerated and biologically active dose for evaluation in Phase II studies.

A Phase I study was undertaken to define the recommended dose of custirsen in combination with docetaxel. ${ }^{69}$ Forty patients with solid tumor types known to overexpress clusterin (prostate, ovary, renal, non-small cell lung, bladder, breast) and with metastatic or locally recurrent disease refractory to curative therapy were enrolled. Custirsen was administered using the same schedule as in the single-agent Phase I study, with loading doses followed by weekly doses of custirsen using the same dose-escalation scheme. Two dose schedules for docetaxel were studied. Schedule A was docetaxel $30 \mathrm{mg} / \mathrm{m}^{2}$ weekly for five of six weeks per cycle for up to four cycles. After the recommended dose of custirsen with weekly docetaxel was established in schedule A, custirsen was studied with three-weekly docetaxel $75 \mathrm{mg} / \mathrm{m}^{2}$ (schedule B), starting at one dose level below the recommended custirsen dose identified in schedule A. The recommended singleagent custirsen dose of $640 \mathrm{mg}$ was well tolerated when administered with either weekly or three-weekly standard docetaxel. Again, dose-dependent decreases in clusterin were noted, with the maximum decrease at the $640 \mathrm{mg}$ dose of custirsen. Serum clusterin levels remained decreased from baseline by $38 \%$ and $34 \%$ with schedule A and B, respectively. Among the patients in the study with CRPC $(\mathrm{n}=15)$, two had a confirmed partial response (based on Response Evaluation Criteria in Solid Tumors) and six had a confirmed PSA response (defined as a $\geq 50 \%$ decline from the baseline level). This study established $640 \mathrm{mg}$ as the recommended Phase II dose for custirsen in combination with docetaxel for prostate cancer and other solid tumors, including breast and lung cancers.

\section{Phase II studies}

\section{Neoadjuvant use in prostate cancer}

A study of 24 patients with localized prostate cancer and high-risk features was conducted to determine the pathologic complete response rate with androgen deprivation therapy and 12 weeks of custirsen $640 \mathrm{mg}$ weekly. ${ }^{66}$ Although there 
Table I Summary of published clinical trials on custirsen in prostate cancer

\begin{tabular}{|c|c|c|}
\hline Study design (clinicaltrials.gov identifier) & Treatment & Patients (n) \\
\hline \multicolumn{3}{|l|}{ Neoadjuvant } \\
\hline \multicolumn{3}{|l|}{ Phase I } \\
\hline $\begin{array}{l}\text { Custirsen with androgen blockade in patients with } \\
\text { previously untreated localized prostate cancer and } \\
\text { high-risk features }{ }^{65} \\
\text { (NCT00054I06) }\end{array}$ & $\begin{array}{l}\text { Custirsen } 40,80,160,320,480 \text {, or } 640 \mathrm{mg} \text { IV loading dose on days I, } \\
3 \text {, and } 5 \text {, then weekly from day } 8 \text { to } 29 \text { plus buserelin acetate } 6.3 \mathrm{mg} \\
\text { injection on day I and flutamide } 250 \mathrm{mg} \text { oral tid for } 28 \text { days } \\
\text { Prostatectomy took place from days } 30-36\end{array}$ & 25 \\
\hline \multicolumn{3}{|l|}{ Phase II } \\
\hline $\begin{array}{l}\text { Custirsen with hormone therapy in patients with } \\
\text { localized prostate cancer and high-risk features }{ }^{66} \\
\text { (NCT00I389/8) }\end{array}$ & $\begin{array}{l}\text { Custirsen } 640 \mathrm{mg} \text { IV loading dose on days I, 3, and 5, then weekly for } \\
\mathrm{I} 2 \text { weeks plus buserelin acetate and flutamide. Prostatectomy took } \\
\text { place within } 2 \text { weeks of the last dose }\end{array}$ & 24 \\
\hline \multicolumn{3}{|l|}{ First-line } \\
\hline \multicolumn{3}{|l|}{ Randomized Phase II } \\
\hline \multirow[t]{2}{*}{$\begin{array}{l}\text { Docetaxel with or without custirsen in first-line } \\
\text { treatment of patients with } \mathrm{mCRPC}^{67} \\
\text { (NCT00258388) }\end{array}$} & $\begin{array}{l}\text { Docetaxel } 75 \mathrm{mg} / \mathrm{m}^{2} \text { IV } 3 \text {-weekly and oral prednisone } 5 \mathrm{mg} \text { bid plus } \\
\text { custirsen } 640 \mathrm{mg} \text { IV (three loading doses during week -I followed by } \\
\text { weekly doses) for up to } 10 \text { cycles }\end{array}$ & 41 \\
\hline & Docetaxel $75 \mathrm{mg} / \mathrm{m}^{2}$ 3-weekly and oral prednisone $5 \mathrm{mg}$ bid & 41 \\
\hline \multicolumn{3}{|l|}{ Second-line } \\
\hline \multicolumn{3}{|l|}{ Randomized Phase II } \\
\hline \multirow[t]{2}{*}{$\begin{array}{l}\text { Custirsen with docetaxel or mitoxantrone in } \\
\text { patients with mCRPC who had progressed } \\
\text { within } 6 \text { months of first-line docetaxel } \\
(\text { CUOG Trial P-06) } \\
\text { (NCT00327340) }\end{array}$} & $\begin{array}{l}\text { Docetaxel } 75 \mathrm{mg} / \mathrm{m}^{2} \text { IV } 3 \text {-weekly and oral prednisone } 5 \mathrm{mg} \text { bid plus } \\
\text { custirsen } 640 \mathrm{mg} \text { IV (three loading doses on week - I followed by } \\
\text { weekly doses) for up to } 9 \text { cycles }\end{array}$ & 20 \\
\hline & $\begin{array}{l}\text { Mitoxantrone } 12 \mathrm{mg} / \mathrm{m}^{2} \text { IV } 3 \text {-weekly and oral prednisone } 5 \mathrm{mg} \text { bid } \\
\text { plus custirsen } 640 \mathrm{mg} \text { IV (three loading doses on week - I followed } \\
\text { by weekly doses) for up to } 9 \text { cycles }\end{array}$ & 22 \\
\hline
\end{tabular}

were no pathologic complete responses, tissue custirsen levels were $>1 \mu \mathrm{g} / \mathrm{g}$, the level at which preclinical effects were seen. In addition, the data confirmed the effects of custirsen on clusterin expression and apoptotic index previously described in the Phase I study of localized disease.

\section{First-line use in combination with docetaxel}

A randomized Phase II study investigated the effect of docetaxel $75 \mathrm{mg} / \mathrm{m}^{2}$ and prednisone $5 \mathrm{mg}$ twice daily with (arm A) and without (arm B) custirsen $640 \mathrm{mg}$ weekly. Eighty-two men with mCRPC who were chemotherapy-naïve were accrued, with 41 patients in each arm. ${ }^{67}$ The primary endpoint was a PSA decline of $\geq 50 \%$ from baseline. This occurred in 58\% of patients in arm A and in 54\% of patients in arm B (Table 1). In patients with measurable disease, partial responses were noted in $19 \%$ and $25 \%$ of patients in arms A and B, respectively. Median progression-free survival was 7.3 months versus 6.1 months and overall survival was 23.8 months versus 16.9 months in arms $\mathrm{A}$ and $\mathrm{B}$, respectively, with an unadjusted hazard ratio of $0.61(95 \%$ confidence interval $0.36-1.02$ ) for overall survival. Serum clusterin levels had decreased by a median of $26 \%$ at the end of the first treatment cycle in arm A, whereas they had increased by a median of $1 \%$ in patients in arm $\mathrm{B}$.

Although the rate of patients achieving a PSA decline of $\geq 50 \%$ from baseline was not significantly improved with 


\begin{tabular}{|c|c|c|c|}
\hline $\begin{array}{l}\text { Survival } \\
\text { (median) }\end{array}$ & Response rate & $\begin{array}{l}\text { PSA change } \\
\text { from baseline }\end{array}$ & Other relevant findings \\
\hline NR & NR & NR & $\begin{array}{l}\text { - Dose-dependent increase in custirsen concentrations in prostate tissue } \\
\text { - Dose-dependent decrease in clusterin expression of }>90 \% \text { in prostate } \\
\text { tissue and lymph nodes, compared with historical controls } \\
\text { - Increase in apoptotic index of prostatectomy specimens (mean } \\
21.2 \% \text { versus } 7-9 \% \text { for historical controls) }\end{array}$ \\
\hline NR & $\mathrm{PCR}, 0 \%$ & NR & $\begin{array}{l}\text { - Custirsen concentrations in prostate tissue }>I \mu \mathrm{g} / \mathrm{g} \\
\text { - Mean clusterin mRNA expression in prostate tissue was decreased by } \\
61 \% \text { versus historical controls } \\
\text { - Increase in apoptotic index of prostatectomy specimens (mean } \\
12.6 \% \text { versus } 7.6 \% \text { for historical controls) }\end{array}$ \\
\hline $\begin{array}{l}\text { OS, } 23.8 \text { months } \\
\text { PFS, } 7.3 \text { months }\end{array}$ & $\begin{array}{l}\text { Number evaluable, } 26 \\
\text { CR, } 0 \% \\
\text { PR, } 19 \% \\
\text { SD, } 77 \% \\
\text { PD, } 4 \%\end{array}$ & $\begin{array}{l}\geq 30 \%, 65 \% \\
\geq 50 \%, 58 \%\end{array}$ & $\begin{array}{l}\text { - Serum clusterin levels decreased from baseline by a median of } 26 \% \text { at } \\
\text { end of first cycle with docetaxel and prednisone and custirsen }\end{array}$ \\
\hline $\begin{array}{l}\text { OS, } 16.9 \text { months } \\
\text { PFS, } 6.1 \text { months }\end{array}$ & $\begin{array}{l}\text { Number evaluable, } 24 \\
\text { CR, } 0 \% \\
\text { PR, } 25 \% \\
\text { SD, } 50 \% \\
\text { PD, } 17 \%\end{array}$ & $\begin{array}{l}\geq 30 \%, 59 \% \\
\geq 50 \%, 54 \%\end{array}$ & $\begin{array}{l}\text { - Serum clusterin levels increased from baseline by a median of } 0.9 \% \text { at } \\
\text { end of first cycle with docetaxel and prednisone alone }\end{array}$ \\
\hline $\begin{array}{l}\text { OS, I } 5.8 \text { months } \\
\text { PFS, } 7.2 \text { months }\end{array}$ & $\begin{array}{l}\text { Number evaluable, } 13 \\
\text { PR, } 15 \% \\
\text { SD, } 69 \%\end{array}$ & $\begin{array}{l}\geq 30 \%, 55 \% \\
\geq 50 \%, 40 \% \\
\geq 90 \%, 20 \%\end{array}$ & $\begin{array}{l}\text { - Clusterin levels during treatment were reduced from baseline by a } \\
\text { mean of } 26 \% \text { in the evaluable study population }(n=40) \\
\text { - } 3 \text { I/40 (78\%) of evaluable patients achieved serum clusterin levels } \\
\text { of } \leq 45 \mu \mathrm{g} / \mathrm{mL}\end{array}$ \\
\hline $\begin{array}{l}\text { OS, II.5 months } \\
\text { PFS, } 3.4 \text { months }\end{array}$ & $\begin{array}{l}\text { Number evaluable } 7 \\
\text { SD, } 71 \%\end{array}$ & $\begin{array}{l}\geq 30 \%, 32 \% \\
\geq 50 \%, 27 \%\end{array}$ & $\begin{array}{l}\text { - } 28 / 40(70 \%) \text { of evaluable patients classified as responders }{ }^{a} \\
\text { - Median time to clusterin response approximately } 30 \text { days }\end{array}$ \\
\hline
\end{tabular}

Notes: ${ }^{2}$ Clusterin responders defined as patients with three successive clusterin levels during therapy $\leq$ median baseline clusterin for the population.

Abbreviations: bid, twice daily; CR, complete response; IV, intravenous; mCRPC, metastatic castration-resistant prostate cancer; mRNA, messenger RNA; NR, not reported; OS, overall survival; PCR, pathologic complete response; PD, progressive disease; PFS, progression-free survival; PR, partial response; PSA, prostate-specific antigen; SD, stable disease; tid, three times daily.

the combination, this study demonstrated that addition of custirsen to docetaxel hit the target, as evidenced by the decrease in clusterin levels compared with no change in arm B. Based on the mechanism of action of custirsen, it was not unexpected that there was no difference observed in the response rates between the two treatment arms in this study. Only those patients with high pretreatment levels of clusterin would be expected to benefit from custirsen, given that patients with low levels of clusterin would normally respond well to chemotherapy alone. However, this was a small Phase II study and was not powered for exploratory analyses. The small number of patients with measurable disease progression in arm A compared with arm B is of interest. In addition, treatment may have been stopped before it was possible to demonstrate a benefit for custirsen in terms of progression-free survival, and a delay in progression may have contributed to the overall survival benefit observed for custirsen. The suggestion of improved overall survival, overall tolerability, and biological effect of the combination provided the basis for further exploration of the combination in Phase III studies in mCRPC.

\section{Second-line use in combination with docetaxel or mitoxantrone}

The preclinical finding that custirsen resensitizes docetaxelrefractory prostate cancer cells ${ }^{45}$ led to initiation of a 

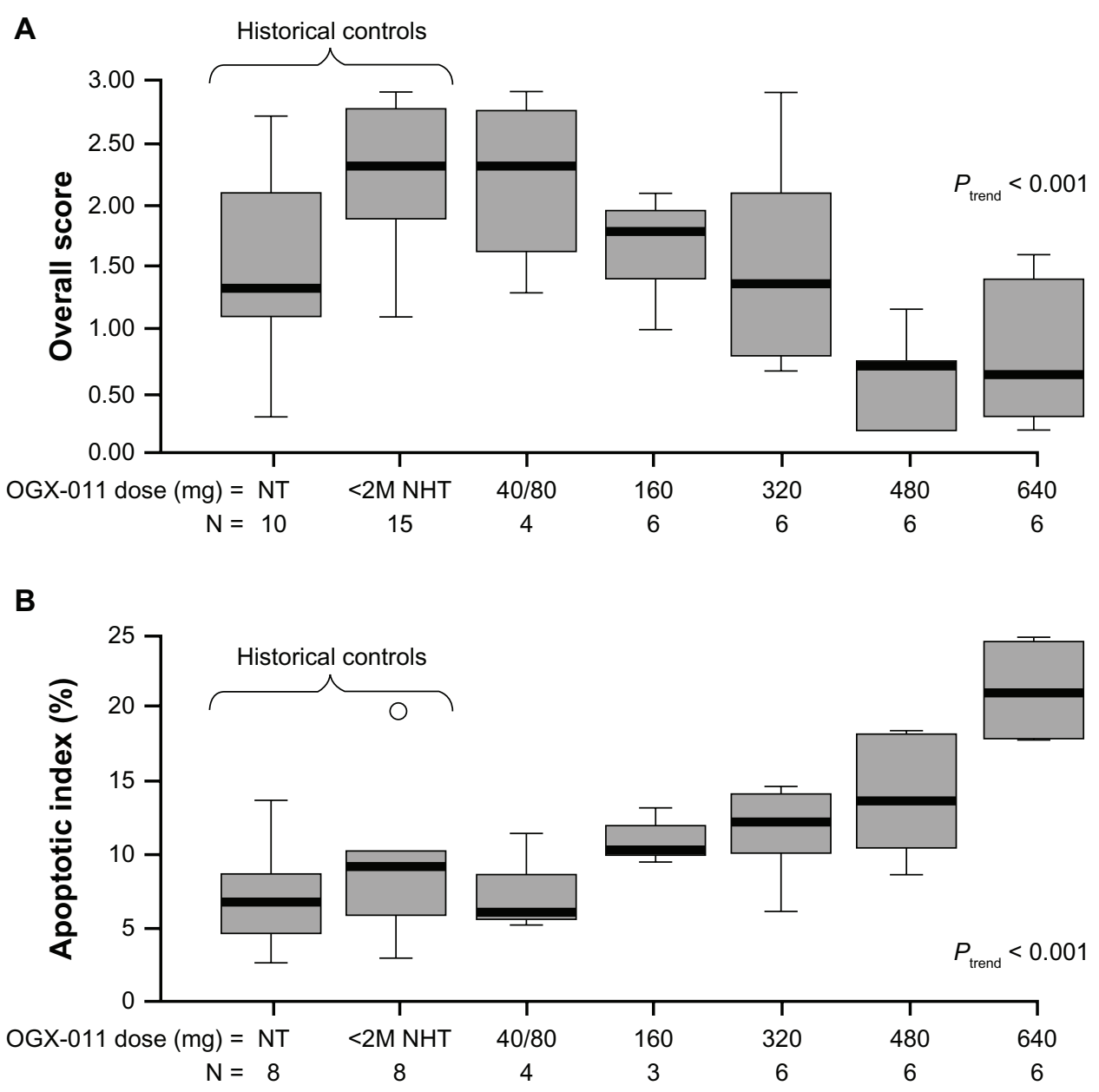

Figure 4 Biological effects of custirsen (OGX-0II) on clusterin expression and apoptotic index in prostate tumor cells from prostatectomy specimens. (A) Box plot of clusterin protein levels in prostate tumor samples from men treated with custirsen and untreated historical controls. (B) Apoptotic index (percentage apoptotic cells and bodies per 10 high-power fields) in prostatectomy specimens and untreated historical controls. ${ }^{65}$

Notes: Boxes represent interquartile ranges, and lines extending from the boxes represent the closer of I.5 times the interquartile range, or the most extreme observation. Lines across the boxes represent the median, and circles represent outliers. Reproduced from Chi KN, Eisenhauer E, Fazli L, Jones EC, Goldenberg SL, Powers J, Tu D, Gleave M. A phase I pharmacokinetic and pharmacodynamic study of OGX-0I I, a 2'-methoxyethyl antisense oligonucleotide to clusterin, in patients with localized prostate cancer. Journal of the National Cancer Insitute. 2005;97(17): 1287-1296, by permission of Oxford University Press. ${ }^{65}$

Abbreviations: $\angle 2 \mathrm{M} \mathrm{NHT}$, less than two months of neoadjuvant hormone therapy; NT, no prior treatment.

randomized Phase II trial (Canadian Urologic Oncology Group [CUOG] trial P-06 $)^{68}$ of patients with mCRPC who had progressed within six months of first-line chemotherapy with docetaxel. Patients were randomized to treatment with custirsen $640 \mathrm{mg}$ weekly with docetaxel $75 \mathrm{mg} / \mathrm{m}^{2}$ and prednisone $5 \mathrm{mg}$ twice daily every three weeks (DPC; $\mathrm{n}=20$ ), or custirsen with mitoxantrone $12 \mathrm{mg} / \mathrm{m}^{2}$ and prednisone $5 \mathrm{mg}$ twice daily every three weeks (MPC; $\mathrm{n}=22$ ). The primary endpoint was safety, and measures of efficacy were exploratory.

The combination of custirsen with either docetaxel or mitoxantrone was well tolerated. With the exception of fatigue and lymphopenia, the toxicities were similar to those seen with first-line docetaxel therapy in the TAX 327 trial. ${ }^{3}$ Lymphopenia is a known class effect of antisense agents and was seen in approximately one-third of patients but without infectious sequelae. Median overall survival for the DPC arm was 15.8 months versus 11.5 months for the MPC arm, and median progression-free survival was 7.2 months and 3.4 months, respectively. More patients in the DPC arm had PSA declines of $\geq 50 \%$ and $\geq 90 \%$ compared with those in the MPC arm (Table 1). For comparison, patients treated with first-line docetaxel in the TAX 327 study who crossed over to second-line mitoxantrone therapy during follow-up had a median overall survival of 10 months and median progression-free survival (defined by PSA progression) of 3.4 months. ${ }^{70}$ A study of patients who received rechallenge with docetaxel as second-line chemotherapy reported a median overall survival of 9.6 months and median time to symptom progression of 4.9 months. ${ }^{71}$ The survival data from this custirsen study also compare favorably 
with those reported for second-line treatment with cabazitaxel (median overall survival 15.1 months). ${ }^{16}$

Overall, $88 \%$ of patients in CUOG Trial P-06 had a durable ( $\geq 3$ months) pain response. Of 13 evaluable patients in each treatment group, $77 \%$ of those in the DPC group responded with a median time to pain progression of 10.0 months compared with $46 \%$ of patients in the MPC group with a median time to pain progression of 5.2 months. As was observed in the other clinical studies, serum clusterin levels were reduced during treatment, and $70 \%$ of 40 evaluable patients were classified as clusterin responders. Low serum clusterin ( $\leq$ median baseline level for the study population) during treatment was shown to be associated with improved survival, with a $70 \%$ reduction in the hazard of death at the time of response $(P<0.001)$. In addition, median overall survival for patients with minimum serum clusterin levels during treatment below the median minimum levels for the population $(n=22)$ was 14.9 months versus 9.9 months for those patients $(\mathrm{n}=18)$ with levels above the median minimum ( $P=0.03$; Figure 5$)$. For those patients who achieved the minimum threshold clusterin levels of $45 \mu \mathrm{g} / \mathrm{mL}$ ( $\mathrm{n}=33$ ), median overall survival was 15 months versus 4.5 months for those who did not achieve this level ( $\mathrm{n}=7, P<0.001 ;$ Figure 5 ).

The findings of this study showed that the combination of custirsen with either docetaxel and prednisone or mitoxantrone and prednisone is feasible in patients who have previously progressed during or after docetaxel chemotherapy, some of whom may have had tumors refractory to docetaxel. The relationship between clusterin levels and survival seen in this study suggests that serum clusterin is a potential biomarker of response to custirsen.

\section{Tolerability of custirsen}

In the first Phase I study of custirsen in prostate cancer, no dose-limiting toxicities were reported at the doses of custirsen investigated (up to $640 \mathrm{mg}$ ); all toxicities were grade $1 / 2$ and typically occurred within the first week of administration ${ }^{65}$ For patients receiving the $640 \mathrm{mg}$ dose, the most frequent adverse events included thrombocytopenia, anemia, and leukopenia, and nonhematologic toxicities, such as fever, fatigue, rigors, and elevation of aspartate/alanine aminotransferase. This toxicity profile is similar to that of other ASOs and many of these toxicities are thought to be due to nonsequence-specific effects of these compounds. ${ }^{72,73}$ A second Phase I study of custirsen in combination with weekly or three-weekly docetaxel in patients with advanced cancer found the combination to be well tolerated, with mainly mild or moderate toxicity. ${ }^{69}$ In this study, four of the
A Median baseline clusterin $=53.5 \mu \mathrm{g} / \mathrm{mL}$

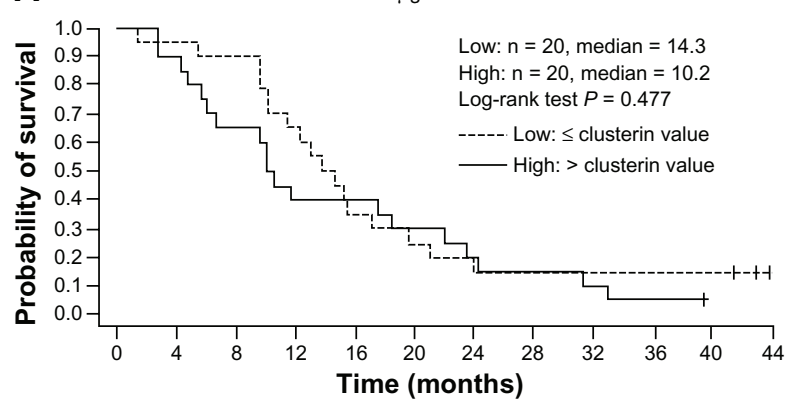

B Median minimum during treatment clusterin $=34.0 \mu \mathrm{g} / \mathrm{mL}$

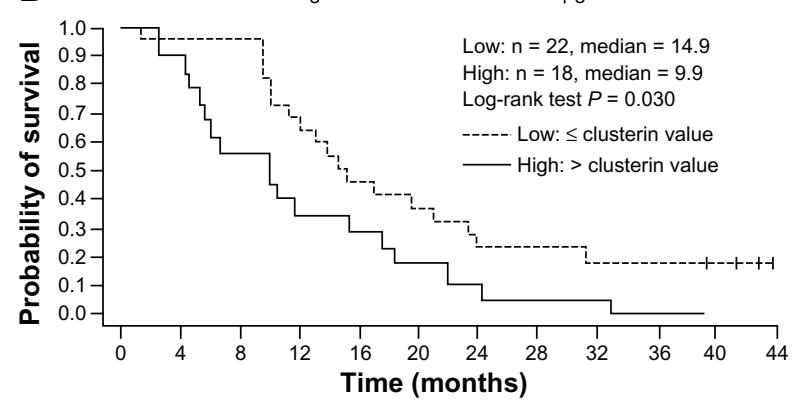

C Threshold minimum during treatment clusterin $=45 \mu \mathrm{g} / \mathrm{mL}$

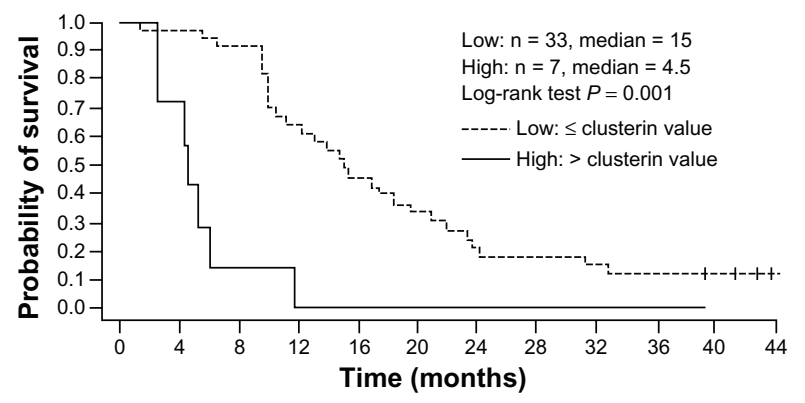

Figure 5 Relationship between overall survival and serum clusterin levels at baseline and during custirsen treatment, based on Kaplan-Meier estimates for dichotomous classifications of patients. (A) Median baseline clusterin ( $\leq$ median versus $>$ median), (B) median minimum clusterin during treatment ( $\leq$ median versus $>$ median); and $(\mathbf{C})$ threshold minimum during treatment with $45 \mu \mathrm{g} / \mathrm{mL}$ ( $\leq 45 \mu \mathrm{g} / \mathrm{mL}$ versus $>45 \mu \mathrm{g} / \mathrm{mL}) .{ }^{68}$

Note: Reprinted from Clinical Cancer Research 20II, volume 17, pages 5765-5773. Saad F, Hotte S, North S, Eigl B, Chi K, Czaykowski P, Wood L, Pollak M, Berry S, Lattouf JB, Mukherjee SD, Gleave M, Winquist E; Canadian Uro-Oncology Group, Randomized phase II trial of custirsen (OGX-0II) in combination with docetaxel or mitoxantrone as second-line therapy in patients with metastatic castrate-resistant prostate cancer progressing after first-line docetaxel: CUOG trial P-06c, with permission from AACR. ${ }^{68}$

16 patients in the $640 \mathrm{mg}$ dose groups experienced doselimiting toxicities (dyspnea/pleural effusion, neutropenia, fatigue, and mucositis). Grade 1 or 2 adverse events that occurred most frequently at the $640 \mathrm{mg}$ dose level included anemia, rigors, fatigue, fever, diarrhea, nausea/vomiting, alopecia, anorexia, mucositis, and elevated hepatic enzymes. Many of the observed toxicities overlap the expected effects of docetaxel, including myelosuppression, fatigue, alopecia, mild/moderate diarrhea, mucositis, fevers, and rigors. 
In Phase II studies, custirsen was well tolerated in combination with docetaxel and prednisone, or with mitoxantrone and prednisone. The toxicities reported with the DPC combination ${ }^{67}$ were consistent with the Phase I results. Frequent grade 1/2 nonhematologic adverse events observed with DPC included fatigue (90\%), sensory neuropathy $(65 \%)$, rigors/chills $(50 \%)$, diarrhea $(58 \%)$, fever $(50 \%)$, nausea $(43 \%)$, and myalgia $(40 \%)$. Fever, rigors, and diarrhea were considered to be related to custirsen, and in most cases the fever and rigors occurred during the first or second loading dose and were of less than 24 hours' duration. Grade 3 or 4 lymphopenia was reported more frequently in the group receiving DPC ( $53 \%$ versus $22 \%$ for docetaxel and prednisone), but was not associated with a higher rate of infection. In the second Phase II trial, in which custirsen was combined with either docetaxel and prednisone or mitoxantrone and prednisone, ${ }^{68}>90 \%$ of adverse events were grade 1 or 2 and were generally similar between the two arms. The most frequent adverse events included fatigue (64\%), chills $(50 \%)$, nausea $(50 \%)$, fever $(40 \%)$, and diarrhea $(36 \%)$. Fatigue and lymphopenia were the most frequent serious adverse events, affecting $29 \%$ and $31 \%$ of all patients, respectively. The rates of other grade $3 / 4$ adverse events reported with the DPC combination in these Phase II studies compare favorably with rates reported in previous studies of docetaxel as first-line or second-line therapy for mCRPC, ${ }^{3,70}$ suggesting that addition of custirsen to docetaxel chemotherapy does not increase the serious toxicities associated with docetaxel therapy.

\section{Ongoing Phase III studies in prostate cancer}

The ongoing Phase III custirsen program in prostate cancer was designed on the basis of preclinical and clinical evidence for activity. Currently, there are two randomized, global Phase III trials of custirsen in combination with chemotherapy compared with the chemotherapy regimen alone. These trials will establish whether custirsen does in fact modulate taxane resistance and improve outcomes such as progression-free survival and overall survival compared with chemotherapy alone. In addition, both trials will measure serum clusterin levels as a potential predictive biomarker. The SYNERGY trial (NCT01188187) is a randomized, open-label study evaluating first-line therapy with custirsen in combination with docetaxel-prednisone versus docetaxel-prednisone alone in men with MCRPC who are chemotherapy-naïve. ${ }^{74}$ The primary endpoint is overall survival. The trial has fully accrued its target, with over 1000 patients enrolled. It is anticipated that survival data will be announced by the first half of 2014. The AFFINITY trial (NCT01578655) is a randomized, open-label trial investigating the survival benefit with second-line treatment after first-line docetaxel with cabazitaxel $25 \mathrm{mg} / \mathrm{m}^{2}$ and prednisone $10 \mathrm{mg} /$ day alone or in combination with custirsen $640 \mathrm{mg}$ weekly. Approximately 630 patients with mCRPC who have progressed after firstline docetaxel will be recruited. This study is expected to be completed by the end of 2015 .

\section{Custirsen in non-small cell lung cancer}

A Phase III trial known as ENSPIRIT (NCT01630733) is comparing docetaxel against docetaxel and custirsen as second-line treatment in 1100 patients with advanced or metastatic non-small cell lung cancer who have failed platinum-based therapy. The primary endpoint is overall survival. The study was initiated in September 2012 and is estimated to be completed by July 2017.

\section{Conclusion}

Clusterin is a cytoprotective chaperone protein that is overexpressed in many tumor types, and is upregulated in response to cellular stress caused by cancer treatments, including hormonal manipulation, radiation, and chemotherapy. Clusterin promotes cell survival during cellular stress and protects against treatment-induced apoptosis. Hence, targeting clusterin is a rational approach to overcoming resistance to cancer therapy. Custirsen is a second-generation ASO that is complementary to clusterin mRNA and potently suppresses clusterin expression in preclinical models of prostate cancer as well as in clinical trials. Prior to embarking on Phase III trials with custirsen, preclinical data were verified in numerous clinical trials. The innovative first-in-human Phase I neoadjuvant trial demonstrated dose-dependent plasma and prostate tissue concentrations of custirsen, which was well tolerated at all dose levels. Importantly, dose-dependent inhibition of clusterin expression was associated with an increase in apoptotic index, demonstrating proof of principle in humans. After a Phase II study of the $640 \mathrm{mg}$ dose had confirmed the tolerability and activity of single-agent custirsen, it was combined with docetaxel to establish the recommended Phase II dose, based on tolerability and maximal inhibition of serum clusterin levels. Subsequently, a randomized Phase II trial compared the combination of docetaxel and custirsen with docetaxel alone. The results of this trial showed that the combination decreased serum clusterin levels, and there was a 
suggestion that overall survival and progression-free survival were improved in comparison with docetaxel alone.

The ongoing Phase III trials of chemotherapy in combination with custirsen versus chemotherapy alone will define whether this combination actually does improve outcomes (overall survival and event-free survival after six cycles of chemotherapy) in mCRPC where so many other docetaxel combination regimens have failed. These Phase III trials will also assess the potential validity of clusterin as a predictive biomarker. Given the role of clusterin in cell survival in response to hormonal or radiation therapy, future trials combining custirsen with these modalities are warranted.

\section{Disclosure}

The author has received clinical trials research funding from OncoGenex, Teva, Aragon Pharmaceuticals, Medivation Inc, Algeta, and Dendreon, and has acted as a consultant for Aragon Pharmaceuticals, Astellas Pharma, Bristol-Myers Squibb, Bayer, Dendreon, and Teva. Medical writing support was provided by Kirsteen Munn of Anthemis Consulting Ltd and funded by Teva Pharmaceutical Industries, Frazer, PA. OncoGenex and Teva each provided a single medical accuracy review of the final draft. The author was not compensated and retained full editorial control over the content of the paper.

\section{References}

1. American Cancer Society. Cancer Facts and Figures 2012. Atlanta, GA: American Cancer Society; 2012.

2. Siegel R, DeSantis C, Virgo K, et al. Cancer treatment and survivorship statistics, 2012. CA Cancer J Clin. 2012;62(4):220-241. Erratum in CA Cancer J Clin. 2012;62:348.

3. Tannock IF, de Wit R, Berry WR, et al. Docetaxel plus prednisone or mitoxantrone plus prednisone for advanced prostate cancer. $N$ Engl J Med. 2004;351:1502-1512.

4. Petrylak DP, Tangen CM, Hussain MH, et al. Docetaxel and estramustine compared with mitoxantrone and prednisone for advanced refractory prostate cancer. $N$ Engl J Med. 2004;351:1513-1520.

5. National Comprehensive Cancer Network. Clinical Practice Guidelines in Oncology (NCCN Guideline $\left.{ }^{\circledR}\right)$. Prostate Cancer. Version 3. Fort Washington, PA: National Comprehensive Cancer Network; 2012.

6. Machiels JP, Mazzeo F, Clausse M, et al. Prospective randomized study comparing docetaxel, estramustine, and prednisone with docetaxel and prednisone in metastatic hormone-refractory prostate cancer. J Clin Oncol. 2008;26:5261-5268.

7. Small E, Demkow T, Gerritsen WR, et al. A Phase III trial of GVAX immunotherapy for prostate cancer in combination with docetaxel versus docetaxel plus prednisone in symptomatic, castration-resistant prostate cancer (CRPC). Abstract 7 presented at the American Society of Clinical Oncology Genitourinary Cancers Symposium, February 26-28, 2009, Orlando, FL.

8. Kelly WK, Halabi S, Carducci M, et al. Randomized, double-blind, placebo-controlled Phase III trial comparing docetaxel and prednisone with or without bevacizumab in men with metastatic castrationresistant prostate cancer: CALGB 90401. J Clin Oncol. 2012;30: 1534-1540.
9. Tannock I, Fizazi K, Ivanov S, et al. Aflibercept versus placebo in combination with docetaxel/prednisone for first-line treatment of men with metastatic castration-resistant prostate cancer (mCRPC): results from the multinational Phase III trial (VENICE). J Clin Oncol. 2013; 31Suppl 6:Abstr 13.

10. Petrylak DP, Fizazi K, Sternberg C, et al. A Phase 3 study to evaluate the efficacy and safety of docetaxel and prednisone (DP) with or without lenalidomide (LEN) in patients with castrate-resistant prostate cancer (CRPC): the MAINSAIL Trial. Abstract LBA24 presented at the European Society for Molecular Oncology Congress, June 6-9, 2012, Berlin, Germany.

11. Armstrong AJ, Creel P, Turnbull J, et al. A Phase I-II study of docetaxel and atrasentan in men with castration-resistant metastatic prostate cancer. Clin Cancer Res. 2008;14:6270-6276.

12. Fizazi K, Higano C, Nelson J, et al. Phase III, randomized, placebocontrolled study of docetaxel in combination with zibotentan (ZD4054) in patients with metastatic castration-resistant prostate cancer. J Clin Oncol. 2013;31:1740-1747.

13. Scher HI, Jia X, Chi K, et al. Randomized, open-label Phase III trial of docetaxel plus high-dose calcitriol versus docetaxel plus prednisone for patients with castration-resistant prostate cancer. J Clin Oncol. 2011;29:2191-2198.

14. Araujo JC, Trudel GC, Saad F, et al. Overall survival (OS) and safety of dasatinib/docetaxel versus docetaxel in patients with metastatic castration-resistant prostate cancer (mCRPC): results from the randomized Phase III READY trial. J Clin Oncol 2012;31 Suppl 6:Abstr LBA8.

15. Kantoff PW, Higano CS, Shore ND, et al. Sipuleucel-T immunotherapy for castration-resistant prostate cancer. $N \mathrm{Engl} \mathrm{J} \mathrm{Med.}$ 2010;363:411-422.

16. de Bono JS, Oudard S, Ozguroglu M, et al. Prednisone plus cabazitaxel or mitoxantrone for metastatic castration-resistant prostate cancer progressing after docetaxel treatment: a randomised open-label trial. Lancet. 2010;376:1147-1154.

17. de Bono JS, Logothetis CJ, Molina A, et al. Abiraterone and increased survival in metastatic prostate cancer. $N$ Engl J Med. 2011;364:1995-2005.

18. Nilsson S, Franzén L, Parker C, et al. Two-year survival follow-up of the randomized, double-blind, placebo-controlled Phase II study of radium-223 chloride in patients with castration-resistant prostate cancer and bone metastases. Clin Genitourin Cancer. 2013;11:20-26.

19. Scher IH, Fizazi K, Saad F, et al. Increased survival with enzalutamide in prostate cancer after chemotherapy. $N$ Engl J Med. 2012;367:1187-1197.

20. Gaestel M. Molecular chaperones in signal transduction. Handb Exp Pharmacol. 2006;172:93-109.

21. Vabulas RM, Raychaudhuri S, Hayer-Hartl M, Hartl FU. Protein folding in the cytoplasm and the heat shock response. Cold Spring Harb Perspect Biol. 2010;2:a004390.

22. Rocchi P, So A, Kojima S, et al. Heat shock protein 27 increases after androgen ablation and plays a cytoprotective role in hormone-refractory prostate cancer. Cancer Res. 2004;64:6595-6602.

23. Zoubeidi A, Chi K, Gleave M. Targeting the cytoprotective chaperone, clusterin, for treatment of advanced cancer. Clin Cancer Res 2010;16:1088-1093.

24. Jones SE, Jomary C. Clusterin. Int J Biochem Cell Biol. 2002;34: $427-431$.

25. Li H, Liu S, Zhu X, Yang S, Xiang J, Chen H. Clusterin immunoexpression and its clinical significance in patients with non-small cell lung cancer. Lung. 2010;188:423-431.

26. Miyake H, Gleave M, Kamidono S, Hara I. Overexpression of clusterin in transitional cell carcinoma of the bladder is related to disease progression and recurrence. Urology. 2002;59:150-154.

27. Rosenberg ME, Silkensen J. Clusterin: physiologic and pathophysiologic considerations. Int J Biochem Cell Biol. 1995;27:633-645.

28. Yu JT, Tan L. The role of clusterin in Alzheimer's disease: pathways, pathogenesis, and therapy. Mol Neurobiol. 2012;45:314-326. 
29. Nizard P, Tetley S, Le Dréan Y, et al. Stress-induced retrotranslocation of clusterin/ApoJ into the cytosol. Traffic. 2007;8:554-565.

30. Humphreys DT, Carver JA, Easterbrook-Smith SB, Wilson MR. Clusterin has chaperone-like activity similar to that of small heat shock proteins. J Biol Chem. 1999;274:6875-6881.

31. Kumita JR, Poon S, Caddy GL, et al. The extracellular chaperone clusterin potently inhibits human lysozyme amyloid formation by interacting with prefibrillar species. J Mol Biol. 2007;369:157-167.

32. Wyatt AR, Yerbury JJ, Berghofer P, et al. Clusterin facilitates in vivo clearance of extracellular misfolded proteins. Cell Mol Life Sci. 2011;68:3919-3931.

33. Zhang Q, Zhou W, Kundu S, et al. The leader sequence triggers and enhances several functions of clusterin and is instrumental in the progression of human prostate cancer in vivo and in vitro. $B J U$ Int. 2006;98:452-460.

34. Zhang H, Kim JK, Edwards CA, et al. Clusterin inhibits apoptosis by interacting with activated Bax. Nat Cell Biol. 2005;7:909-915.

35. Zoubeidi A, Ettinger S, Beraldi E, et al. Clusterin facilitates COMMD1 and I-kappa B degradation to enhance NF-kappa B activity in prostate cancer cells. Mol Cancer Res. 2010;8:119-130.

36. Shiota M, Zardan A, Takeuchi A, et al. Clusterin mediates TGF- $\beta$ induced epithelial-mesenchymal transition and metastasis via Twist 1 in prostate cancer cells. Cancer Res. 2012;72:5261-5272.

37. Kevans D, Foley J, Tenniswood M, et al. High clusterin expression correlates with a poor outcome in stage II colorectal cancers. Cancer Epidemiol Biomarkers Prev. 2009;18:393-399.

38. Kurahashi T, Muramaki M, Yamanaka K, Hara I, Miyake H. Expression of the secreted form of clusterin protein in renal cell carcinoma as a predictor of disease extension. BJU Int. 2005;96:895-899.

39. Redondo M, Villar E, Torres-Muñoz J, Tellez T, Morell M, Petito CK. Overexpression of clusterin in human breast carcinoma. Am J Pathol. 2000;157:393-399.

40. Steinberg J, Oyasu R, Lang S, et al. Intracellular levels of SGP-2 (clusterin) correlate with tumor grade in prostate cancer. Clin Cancer Res. 1997;3:1707-1711.

41. Xie D, Lau SH, Sham JS, et al. Upregulated expression of cytoplasmic clusterin in human ovarian carcinoma. Cancer. 2005;103:277-283.

42. Cochrane DR, Wang Z, Muramaki M, Gleave ME, Nelson CC. Differential regulation of clusterin and its isoforms by androgens in prostate cells. J Biol Chem. 2007;282:2278-2287.

43. July LV, Akbari M, Zellweger T, Jones EC, Goldenberg SL, Gleave ME. Clusterin expression is significantly enhanced in prostate cancer cells following androgen withdrawal therapy. Prostate. 2002;50:179-188.

44. Patterson SG, Wei S, Chen X, et al. Novel role of Stat1 in the development of docetaxel resistance in prostate tumor cells. Oncogene. 2006;25:6113-6122.

45. Sowery RD, Hadaschik BA, So AI, et al. Clusterin knockdown using the antisense oligonucleotide OGX-011 re-sensitizes docetaxelrefractory prostate cancer $\mathrm{PC}-3$ cells to chemotherapy. $B J U$ Int. 2008;102:389-397.

46. Miyake H, Nelson C, Rennie PS, Gleave ME. Testosteronerepressed prostate message- 2 is an antiapoptotic gene involved in progression to androgen independence in prostate cancer. Cancer Res. 2000;60:170-176.

47. Miyake H, Nelson C, Rennie PS, Gleave ME. Acquisition of chemoresistant phenotype by overexpression of the antiapoptotic gene testosteronerepressed prostate message- 2 in prostate cancer xenograft models. Cancer Res. 2000;60:2547-2554.

48. Zellweger T, Kiyama S, Chi K, et al. Overexpression of the cytoprotective protein clusterin decreases radiosensitivity in the human $\mathrm{LNCaP}$ prostate tumour model. BJU Int. 2003;92:463-469.

49. Gleave ME, Monia BP. Antisense therapy for cancer. Nat Rev Cancer. 2005;5:468-479.

50. Bedikian AY, Millward M, Pehamberger H, et al. Bcl-2 antisense (oblimersen sodium) plus dacarbazine in patients with advanced melanoma: the Oblimersen Melanoma Study Group. J Clin Oncol. 2006;24:4738-4745.
51. Chanan-Khan AA, Niesvizky R, Hohl RJ, et al. Phase III randomised study of dexamethasone with or without oblimersen sodium for patients with advanced multiple myeloma. Leuk Lymphoma. 2009;50:559-565.

52. ISIS Pharmaceuticals. Available from: http://ir.isispharm.com/phoenix. zhtml?c=222170\&p=irol-newsArticle_pf\&ID=1290234\&highlight. Accessed January 8, 2013.

53. Zellweger T, Miyake H, Cooper S, et al. Antitumor activity of antisense clusterin oligonucleotides is improved in vitro and in vivo by incorporation of 2'-O-(2-methoxy)ethyl chemistry. J Pharmacol Exp Ther. 2001;298:934-940.

54. Monia BP, Lesnik EA, Gonzalez C, et al. Evaluation of 2'-modified oligonucleotides containing 2 -deoxy gaps as antisense inhibitors of gene expression. J Biol Chem. 1993;268:14514-14522.

55. Henry S, Stecker K, Brooks D, Monteith D, Conklin B, Bennett CF. Chemically modified oligonucleotides exhibit decreased immune stimulation in mice. J Pharmacol Exp Ther. 2000;292:468-479.

56. Chi KN, Hotte SJ, Ellard S, et al. A randomized Phase II study of OGX427 plus prednisone $(\mathrm{P})$ versus $\mathrm{P}$ alone in patients (pts) with metastatic castration resistant prostate cancer (CRPC). J Clin Oncol. 2012;30 Suppl:Abstr 4514

57. Chi KN, Hotte SJ, Ellard S, et al. A randomized Phase II study of OGX-427 plus prednisone versus prednisone alone in patients with chemotherapy-naive metastatic castration-resistant prostate cancer. J Clin Oncol. 2012;30 Suppl 5:Abstr 121.

58. So AI, Black PC, Chi KN, et al. A Phase I trial of intravesical antisense oligonucleotide targeting heat shock protein 27 (OGX-427) for the treatment of non-muscle-invasive bladder cancer. J Clin Oncol. 2012; 30 Suppl 5:Abstr 286

59. Talbot DC, Ranson M, Davies J, et al. Tumor survivin is downregulated by the antisense oligonucleotide LY2181308: a proof-of-concept, firstin-human dose study. Clin Cancer Res. 2010;16:6150-6158.

60. Cao C, Shinohara ET, Li H, et al. Clusterin as a therapeutic target for radiation sensitization in a lung cancer model. Int J Radiat Oncol Biol Phys. 2005;63:1228-1236.

61. So A, Sinnemann S, Huntsman D, Fazli L, Gleave M. Knockdown of the cytoprotective chaperone, clusterin, chemosensitizes human breast cancer cells both in vitro and in vivo. Mol Cancer Ther. 2005;4:1837-1849.

62. Gleave M, Miyake H. Use of antisense oligonucleotides targeting the cytoprotective gene, clusterin, to enhance androgen- and chemosensitivity in prostate cancer. World J Urol. 2005;23:38-46.

63. July LV, Beraldi E, So A, et al. Nucleotide-based therapies targeting clusterin chemosensitize human lung adenocarcinoma cells both in vitro and in vivo. Mol Cancer Ther. 2004;3:223-232.

64. Muramaki M, So A, Hayashi N, et al. Chemosensitization of gemcitabine-resistant human bladder cancer cell line both in vitro and in vivo using antisense oligonucleotide targeting the anti-apoptotic gene, clusterin. BJU Int. 2009;103:384-390.

65. Chi KN, Eisenhauer E, Fazli L, et al. A Phase I pharmacokinetic and pharmacodynamic study of OGX-011, a 2'-methoxyethyl antisense oligonucleotide to clusterin, in patients with localized prostate cancer. J Natl Cancer Inst. 2005;97:1287-1296.

66. Chi KN, Goldenberg L, Kollmannsberger C, Murray N, Fazli L, Gleave ME. A Phase II neoadjuvant study of OGX-011, a 2'methoxyethyl phosphorothioate antisense to clusterin, in patients with prostate cancer prior to prostatectomy. Abstract 167 presented at the American Society of Clinical Oncology Genitourinary Cancers Symposium, February 14-16, 2008, San Francisco, CA.

67. Chi KN, Hotte SJ, Yu EY, et al. Randomized Phase II study of docetaxel and prednisone with or without OGX-011 in patients with metastatic castration-resistant prostate cancer. J Clin Oncol. 2010;28:4247-4254

68. Saad F, Hotte S, North S, et al. Randomized Phase II trial of custirsen (OGX-011) in combination with docetaxel or mitoxantrone as secondline therapy in patients with metastatic castrate-resistant prostate cancer progressing after first-line docetaxel: CUOG Trial P-06. Clin Cancer Res. 2011;17:5765-5773. 
69. Chi KN, Siu LL, Hirte H, et al. A Phase I study of OGX-011, a 2'-methoxyethyl phosphorothioate antisense to clusterin, in combination with docetaxel in patients with advanced cancer. Clin Cancer Res. 2008;14:833-839.

70. Berthold DR, Pond GR, de Wit R, Eisenberger M, Tannock IF; for the TAX 327 Investigators. Survival and PSA response of patients in the TAX 327 study who crossed over to receive docetaxel after mitoxantrone or vice versa. Ann Oncol. 2008;19:1749-1753.

71. Jankovic B, Beardsley E, Chi KN. Rechallenge with docetaxel as secondline chemotherapy in patients with metastatic hormone refractory prostate cancer (HRPC) after previous docetaxel: a population based analysis. Abstract 196 presented at the American Society of Clinical Oncology Genitourinary Cancers Symposium, February 14-16, 2008, San Francisco, CA.
72. Nemunaitis J, Holmlund JT, Kraynak M, et al. Phase I evaluation of ISIS 3521, an antisense oligodeoxynucleotide to protein kinase C-alpha, in patients with advanced cancer. J Clin Oncol. 1999;17:3586-3595.

73. Waters JS, Webb A, Cunningham D, et al. Phase I clinical and pharmacokinetic study of bcl-2 antisense oligonucleotide therapy in patients with non-Hodgkin's lymphoma. J Clin Oncol. 2000;18:1812-1823.

74. Chi KN, De Bono JS, Higano CS. SYNERGY: a randomized Phase III study comparing first-line docetaxel/prednisone to docetaxel/prednisone plus custirsen in metastatic castrate-resistant prostate cancer (mCRPC). J Clin Oncol. 2011 Suppl:Abstr TPS180.

\section{Publish your work in this journal}

OncoTargets and Therapy is an international, peer-reviewed, open access journal focusing on the pathological basis of all cancers, potential targets for therapy and treatment protocols employed to improve the management of cancer patients. The journal also focuses on the impact of management programs and new therapeutic agents and protocols on

\section{Dovepress}

patient perspectives such as quality of life, adherence and satisfaction The manuscript management system is completely online and includes a very quick and fair peer-review system, which is all easy to use. Visit http://www.dovepress.com/testimonials.php to read real quotes from published authors.

Submit your manuscript here: http://www.dovepress.com/oncotargets-and-therapy-journal 